\title{
PENYULUHAN DAN PELATIHAN KERJA SAMA TIM PADA ANGGOTA ORGANISASI KEMASYARAKATAN PEMUDA KATOLIK CABANG TOMOHON
}

\author{
Jones Xaverius Pontoh \\ Fakultas Ekonomi, Universitas Negeri Manado \\ jonesjilly2@gmail.com
}

\begin{abstract}
Abstrak
The article was trying to implement and solve teamwork issues in the Pemuda Katolik organization. The organization was a non government organization that have stucture nationally. The object of the the research was Pemuda Katolik in Tomohon Region. In their daily movement often facing problems in teamwork. Many programmes cannot result in satisfiying outcomes and acihevement due to lack of understanding and team work. The research was trying to help the organization to solve the problems and icrease the organization achievements. The methode were lecturing, group discussions, event studies and field simulations. The result the evaluated through soem criteria consist of quality of the process, outcomes and achievements of the participants. The result showed that there have been an increase of knowledge and ability in creating and initiating team work significantly. All participants past the simulation test and qualitatively agreed that they have better understanding in developing team work in pursuing organization goals.

Kata Kunci: Team work, Pemuda Katolik
\end{abstract}

\section{PENDAHULUAN}

\section{Analisis Situasi}

Pemuda Katolik adalah sebuah organisasi kemasyarakatan yang berbasis orang muda katolik. Pemuda Katolik cabang Tomohon beranggotakan sedikitnya 250 anggota yang aktif dalam organisasi. PK berbasis Muda Mudi Gereja Katolik. Hal ini membuat sumber keanggotaan seharusnya terbuka lebar dari segi kuantitas. Namun dalam kenyataannya keanggotaan organisasi kemasyarakatan ini jika dibandingkan jumlah muda mudi katolik yang ada di tomohon sangatlah kecil proporsinya.

Sesuai observasi dan wawancara dengan ketua presidium penulis menarik kesimpulan bahwa salah satu hal yang ingin diperbaiki oleh presidium adalah masalah kerja sama tim. Dalam wawancara ketua presidium mengungkapkan bahwa sering terjadi permasalahan di lapangan akibat kurangnya koordinasi dan kerja sama antar aggota. Bahkan pernah ada suatu masa dimana para anggota bergerak secara sendiri-sendiri secara sporadis. Hal ini menyebabkan hasil kerja yang dicapai kurang optimal dan tujuan yang ingin dicapai kadang bias

\section{Tujuan dan Manfaat}

Penyuluhan dan pelatihan ini bertujuan untuk memberikan pembinaan dan pelatihan kepada anggota Perhimpunan Mahasiswa Katolik Cabang Tomohon tentang bagaimana membangun kerja sama tim dan mengambil keputusan bersama. Secara lebih khusus, tujuan dari penyuluhan dan pelatihan ini adalah membantu para 
anggota agar mengerti dan terlatih dalam hal-hal sebagai berikut:

a. Membangun tim yang efektif

b. Bagaimana peran pemimpin dalam kerja sama tim yang efektif

c. Pemecahan masalah dengan win-win solution

d. Mengidentifikasi keadaan dimana kerja sama tim dibutuhkan

Adapun sasaran dari kegiatan ini adalah pembinaan dan pelatihan kepada anggota PEMUDA KATOLIK cabang Kota Tomohon. Pembinaan dan Pelatihan ini bermanfaat bagi para anggota PEMUDA KATOLIK untuk memahami dan melatih kerja sama tim, membangun tim yang efektif serta dapat bisa memecahkan masalah dengan win-win solution.

\section{TINJAUAN LITERATUR}

\section{Pengertian Team Work}

Penyelenggaraan teamwork dilakukan karena pada saat ini tekanan persaingan semakin meningkat, para ahli menyatakan bahwa keberhasilan organisasi akan semakin bergantung pada teamwork daripada bergantung pada individu-individu yang menonjol. Konsep tim maknanya terletak pada ekspresi yang menggambarkan munculnya sinergi pada orangorang yang mengikatkan diri dalam kelompok yang disebut dengan tim.

Tracy (2006) menyatakan bahwa teamwork merupakan kegiatan yang dikelola dan dilakukan sekelompok orang yang tergabung dalam satu organisasi. 68
Teamwork dapat meningkatkan kerja sama dan komunikasi di dalam dan di antara bagian-bagian perusahaan. Biasanya teamwork beranggotakan orang-orang yang memiliki perbedaan keahlian sehingga dijadikan kekuatan dalam mencapai tujuan perusahaan.

Pernyataan di atas diperkuat Dewi (2007) kerja tim (teamwork) adalah bentuk kerja dalam kelompok yang harus diorganisasi dan dikelola dengan baik. Tim beranggotakan orang-orang yang memiliki keahlian yang berbeda-beda dan dikoordinasikan untuk bekerja sama dengan pimpinan. Terjadi saling ketergantungan yang kuat satu sama lain untuk mencapai sebuah tujuan atau menyelesaikan sebuah tugas. Dengan melakukan teamwork diharapkan hasilnya melebihi jika dikerjakan secara perorangan.

$$
\text { Stephen dan Timothy }
$$
menyatakan teamwork adalah kelompok yang usaha-usaha individualnya menghasilkan kinerja lebih tinggi daripada jumlah masukan individual. Teamwork menghasilkan sinergi positif melalui usaha yang terkoordinasi. Hal ini memiliki pengertian bahwa kinerja yang dicapai oleh sebuah tim lebih baik daripada kinerja perindividu di suatu organisasi ataupun suatu perusahaan.

Teori yang dikemukakan oleh Stephen dan Timothy (2008) senada dengan teori tim yang efektif yang dikemukakan oleh Smither, Houston, McIntire (1996). Manurut Smither, Houston, McIntire (1996), 
tim yang efektif adalah sebuah tim yang memungkinkan anggotanya untuk bisa menghasilkan penyelesaian tugas yang lebih besar jumlahnya dibandingkan dengan hasil kerja perorangan karena hasil kerjanya merupakan hasil dari kontribusi anggotaanggota tim secara bersama-sama.

\section{Jenis Team Work}

$$
\text { Menurut Daft (2000) jenis }
$$
teamwork terdiri dari 6 (enam) jenis, yaitu:

1. Tim Formal, adalah sebuah tim yang dibentuk oleh organisasi sebagai bagian dari struktur organisasi formal;

2. Tim Vertikal, adalah sebuah tim formal yang terdiri dari seorang manajer dan beberapa orang bawahannya dalam rantai komando organisasi formal;

3. Tim Horizontal, adalah sebuah tim formal yang terdiri dari beberapa karyawan dari tingkat hirarki yang hampir sama tapi berasal dari area keahlian yang berbeda;

4. Tim dengan Tugas Khusus, adalah sebuah tim yang dibentuk diluar organisasi formal untuk menangani sebuah proyek dengan kepentingan atau kreativitas khusus;

5. Tim Mandiri, adalah sebuah tim yang terdiri dari 5 hingga 20 orang pekerja dengan beragam keterampilan yang menjalani rotasi pekerjaan untuk menghasilkan sebuah produk atau jasa secara lengkap, dan pelaksanaannya diawasi oleh seorang annggota terpilih; dan
6. Tim Pemecahan Masalah, adalah biasanya terdiri dari 5 hingga 12 karyawan yang dibayar perjam dari departemen yang sama, dimana mereka bertemu untuk mendiskusikan cara memperbaiki kualitas, efisiensi, dan lingkungan kerja.

\section{Tahap Perkembangan Team Work}

Hal yang sangat mendasar dalam mewujudkan keutuhan sebuah tim agar dapat berkinerja dan berdaya guna adalah dengan melakukan perancangan tim yang baik. Pentingnya perancangan tim yang baik diuraikan Griffin (2004) dengan membagi ke dalam 4 (empat) tahap perkembangan, yaitu:

1. Forming (pembentukan), adalah tahapan di mana para anggota setuju untuk bergabung dalam suatu tim. Karena kelompok baru dibentuk maka setiap orang membawa nilai-nilai, pendapat dan cara kerja sendiri-sendiri. Konflik sangat jarang terjadi, setiap orang masih sungkan, malu-malu, bahkan seringkali ada anggota yang merasa gugup. Kelompok cenderung belum dapat memilih pemimpin (kecuali tim yang sudah dipilih ketua kelompoknya terlebih dahulu);

2. Storming (merebut hati), adalah tahapan di mana kekacauan mulai timbul di dalam tim. Pemimpin yang telah dipilih seringkali dipertanyakan kemampuannya dan anggota kelompok tidak ragu-ragu untuk mengganti pemimpin yang dinilai tidak mampu. 
Faksi-faksi mulai terbentuk, terjadi pertentangan karena masalah-masalah pribadi, semua bersikeras dengan pendapat masing-masing. Komunikasi yang terjadi sangat sedikit karena masing-masing orang tidak mau lagi menjadi pendengar;

3. Norming (pengaturan norma), adalah tahapan di mana individu-individu dan subgroup yang ada dalam tim mulai merasakan keuntungan bekerja bersama dan berjuang untuk menghindari team tersebut dari kehancuran (bubar). Karena semangat kerjasama sudah mulai timbul, setiap anggota mulai merasa bebas untuk mengungkapkan perasaan dan pendapatnya kepada seluruh anggota tim; dan

4. Performing (melaksanakan), adalah tahapan merupakan titik kulminasi di mana team sudah berhasil membangun sistem yang memungkinkannya untuk dapat bekerja secara produktif dan efisien. Pada tahap ini keberhasilan tim akan terlihat dari prestasi yang ditunjukkan.

\section{Peranan Anggota Tim}

Selanjutnya Williams (2008) membagi ada 5 (lima) hal yang menunjukkan peranan anggota dalam membangun kerja tim yang efektif, yaitu:

1. Para anggota mengerti dengan baik tujuan tim dan hanya dapat dicapai dengan baik pula dengan dukungan bersama, dan oleh karena itu mempunyai rasa saling ketergantungan, rasa saling memiliki tim dalam melaksanakan tugas;

2. Para anggota menyumbang keberhasilan tim dengan menerapkan bakat dan pengetahuannya untuk sasaran tim, dapat bekerja dengan secara terbuka, dapat mengekspresikan gagasan, opini dan ketidaksepakatan, peranan dan pertanyaannya disambut dengan baik;

3. Para anggota berusaha mengerti sudut pandang satu sama lain, didorong untuk mengembangkan keterampilannya dan menerapkan pada pekerjaan, untuk itu mendapat dukungan dari tim;

4. Para anggota mengakui bahwa konflik adalah hal yang normal, atau hal yang biasa, dan berusaha memecahkan konflik tersebut dengan cepat dan konstruktif (bersifat memperbaiki); dan

5. Para anggota berpartisipasi dalam keputusan tim, tetapi mengerti bahwa pemimpin mereka harus membuat peraturan akhir setiap kali tim tidak berhasil membuat suatu keputusan, dan peraturan akhir itu bukan merupakan persesuaian.

\section{Dimensi Tim yang Efektif}

Menurut Johnson dan Johnson (dalam Smither, Houston, dan Mclntire, 1996), ada 9 dimensi dalam model efektifitas tim yang dapat digunakan untuk mengevaluasi anggota tim dan mengidentifikasikan kekuatan serta kelemahan yang ada di dalam tim, yaitu: 
1. Pemahaman, relevansi, dan komitmen pada tujuan. Setiap anggota tim harus memahami tujuan tim secara jelas dan memiliki kemauan untuk mewujudkan tujuan-tujuan tim karena tujuan tim adalah merupakan hasil dari tujuan bersama dimana tujuan tim pada akhirnya akan mendorong terwujudnya kerjasama dalam tim sehingga kerjasama dalam tim mampu untuk meningkatkan prestasi, produktivitas, dan menciptakan hubungan kerja yang positif diantara sesama anggotanya;

2. Komunikasi mengenai ide dan perasaan. Komunikasi di antara anggota tim harus melibatkan penyampaian dan penerimaan informasi tentang ide-ide dan perasaan. Dalam tim yang tidak efektif, komunikasi sering satu arah dan memfokuskan secara eksklusif hanya pada ide saja. Dengan mengabaikan atau menekan perasaan, maka tim berisiko kehilangan informasi yang berharga dan dapat melemahkan kohesivitas tim;

3. Kepemimpinan yang berpartisipasi. Kepemimpinan harus berpartisipasi dan mendistribusikan peran kepemimpinannya kepada semua anggota tim;

4. Fleksibel dalam menggunakan prosedur pembuatan keputusan. Prosedur pengambilan keputusan harus sesuai dengan kebutuhan tim dan sifat keputusannya. Keterbatasan waktu, keterampilan anggota dan implikasi dari semua keputusan tim harus dinilai secara hati-hati. Sebagai contoh, ketika keputusan- keputusan penting dibuat maka akan membutuhkan dukungan dari anggota tim untuk mengimplementasikan dan melakukan strateginya dengan efektif;

5. Manajemen konflik yang konstruktif. Tim yang tidak efektif sering mencoba untuk mengabaikan atau menekan konflik, sedangkan tim yang efektif dapat menggunakan konflik dengan cara yang konstruktif. Ketika dikelola dengan baik, konflik dapat menyebabkan pengambilan keputusan yang baik pula yakni memecahkan masalah dengan lebih kreatif, dan jumlah partisipasi anggota tim yang lebih tinggi;

6. Kekuasaan berdasarkan keahlian, kemampuan, dan informasi. Anggota tim harus mampu mempengaruhi dan dipengaruhi oleh orang lain untuk mengkoordinasikan kegiatan tim. Kekuasaan dan saling mempengaruhi ini harus terwujudkan secara merata dalam tim. Apabila kekuasaan dan kegiatan saling mempengaruhi ini hanya dipusatkan pada beberapa orang anggota tim saja maka kemungkinan efektifitas tim, komunikasi dan kohesivitas tim akan menjadi berkurang;

7. Kohesi tim. Dalam tim yang kohesif, setiap anggota merasa saling menyukai antara satu sama lainnya dan merasa puas dengan keanggotaan tim mereka. Meskipun kohesi tidak mengarah kepada efektifitas namun ia memiliki peranan yang penting dalam mewujudkan tim yang efektif yaitu ketika ia 
dikombinasikan dengan dimensi lain dari efektifitas tim maka sebuah tim yang memiliki kohesivitas yang tinggi cenderung meningkatkan produktivitas;

8. Strategi pemecahan masalah. Tim harus mampu mengenali masalah dan menghasilkan solusi secara tepat. Setelah solusinya diimplementasikan, tim harus mengevaluasi keefektifan dari solusi tersebut. Ketika sebuah tim mampu untuk mengenali masalahmasalah yang sering muncul dan menyelesaikannya dengan memberikan solusi yang tepat maka sebuah tim yang efektif juga akan mampu untuk mengidentifikasikan kemungkinan-kemungkinan masalah-masalah yang akan muncul dikemudian hari serta mampu memberikan solusi yang inovatif; dan

9. Efektivitas interpersonal. Anggota tim harus mampu untuk berinteraksi dengan anggota tim lainnya secara efektif sehingga membuat efektifitas interpersonal anggota tim menjadi meningkat. Efektifitas interpersonal dapat diukur dengan menggabungkan konsekuensi tindakan anggota kelompok dengan tujuan anggota tim. Kecocokan antara tujuan anggota tim dan konsekuensi dari peningkatan perilaku mereka, maka membuat interpersonal efektifitas anggota tim juga juga menjadi meningkat.

Richard Y. Chang \& Mark J. Curtin (1998) menyatakan manfaat tim bagi individu dan tim bagi organisasi, yaitu: a. Manfaat tim bagi individu:

1) Pekerjaan lebih bervariasi;

2) Lebih banyak kebebasan untuk membuat dan menindaklanjuti keputusan yang benar; dan

3) Meningkatkan kesempatan untuk mempelajari keahlian baru.

b. Manfaat tim bagi organisasi

1) Meningkatkan komitmen terhadap keputusan yang diambil;

2) Meningkatkan produktivitas tim;

3) Lebih fleksibel dalam operasional kerja; dan

4) Meningkatkan rasa tanggung-jawab.

\section{Kerangka Pemecahan Masalah}

Masalah yang dihadapi oleh organisasi kemasyarakatan Pemuda katolik adalah sebagai berikut:

1. Proses eksekusi program di lapangan belum bisa dilakukan secara optimal karena kurangnya kerja sama;

2. Para kader cenderung memiliki cara dan tujuan masing masing dalam pelaksanaan program kemasyarakatan;

3. Hasil yang dicapai dirasa kurang optimal oleh pemimpin; dan

4. Kenyataan di lapangan mengatakan bahwa banyak anggota yang kemudian pasif karena kurang kerja sama dengan anggota lain yang ada dalam organisasi.

Untuk bisa mengantar para anggota pada kemampuan untuk membangun kerjasama yang baik diperlukan metode tertentu. kemampuan dasar untuk bekerja sam tidak langsung dimiliki oleh setiap 
anggota. Untuk itu perlu ada penyeragaman persepsi mengenai pentingnya kerja sama tim dalam suatu oraganisasi.

Ketika semua anggota telah menyadari pentingnya kerja sama tim, diperlukan latihan dan pengembangan kemampuan agar bisa membangun tim yang baik. Untuk itu diperlukan simulasi, praktek dan pengalaman langsung dari anggota.

Pada akhir penyuluhan dan pelatihan ini diharapkan anggota telah menguasai dan mampu membangun kerja sama tim yang baik agar bisa menyelesaikan permasalahan dan tantangan serta kewajiban dengan optimal.

\section{METODE PELAKSANAAN}

\section{Pelaksanaan Kegiatan}

Kegiatan Penyuluhan dan Pelatihan kerja sama tim ini dilaksanakan bekerja sama dengan pengurus Organisasi Pemuda Katolik Cabang Tomohon. Seluruh Anggota diundang dalam kegiatan ini, terlebih yang masih kurang dari 3 tahun menjadi anggota.

Peserta yang hadir ada 30 orang yang berasal dari anggota ranting yang tersebar di kota Tomohon. Kegiatan ini dipusatkan di kelurahan Kinilow mengambil tempat yang cocok untk dilakukan kegiatan semacam pemusatan. Kegiatan ini dilaksanakan pada tanggal 29-30 Mei 2013.

\section{Materi, Metode, Teknik yang Digunakan dan Evaluasi}

Rencana materi yang akan diberikan mencakup : a. Bagaimana membangun tim yang efektif

b. Bagaimana peran pemimpin dalam kerja sama tim yang efektif

c. Pemecahan masalah dengan win-win solution

d. Simulasi dan games yang membangun kerja sama tim

Metode yang digunakan dalam kegiatan pengabdian ini adalah metode ceramah, tanya jawab, studi kasus, games dan praktek lapangan. Teknik yang digunakan dalam kegiatan ini adalah secara individual dan kelompok. Evaluasi akan dilakukan baik pada setiap kegiatan pembinaan dan pelatihan maupun pada saat kegiatan berakhir

\section{HASIL DAN PEMBAHASAN}

Kegiatan ini dilaksanakan sebagai wujud nyata kepedulian terhadap kaum muda bangsa Indonesia yang terus berkembang. Kaum Muda perlu semakin dewasa dalam bertindak dan semakin maju dengan bekal pengetahuan dan keterampilan dalam hidup.

Membangun kerja sama tim tidak hanya diperlukan dalam organisasi kaum muda, tapi juga dalam kehidupan sehari hari serta dalam masa depan mereka dalam dunia pekerjaan dan lingkungan masyarakat.

Keberhasilan kegiatan ini bukan semata mata diukur dari jumlah peserta yang ikut tapi dari output yang dihasilkan setelah kegiatan ini dilaksanakan. Selama kegiatan ini dilansungkan telah banyak 
perkembangan yang terjadi sesuain dengan pengamatan. Kemampuan bersosialisasi, berkomunikasi serta bekerja sama semakin meningkat.
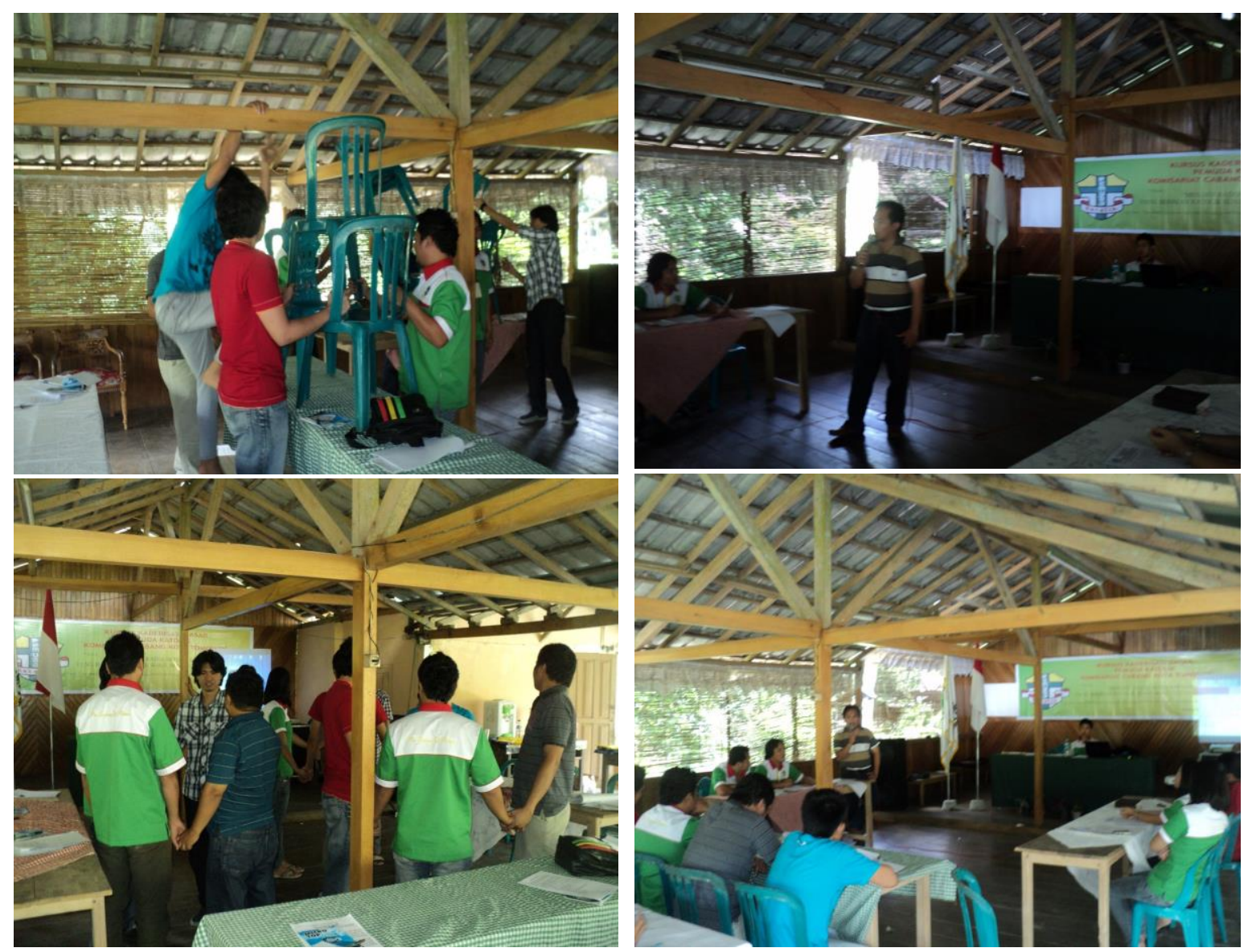

\section{Gambar 1. Dokumentasi Kegiatan}

Sebagai contoh sederhana, pada awal kegiatan ini, setelah menerima pemaparan materi, para anggota banyak yang belum saling kenal. Mereka kemudian dikelompokkan secara acak dan diberikan tugas studi kasus dan simulasi kerja sama tim. Pada awalnya memang hasilnya tidak maksimal. Hal ini disebabkan karena mereka belum bisa mengaplikasikan teori yang sudah diberikan. Setelah beberapa simulasi, mereka akhirnya mampu menangkap maksudnya dan mulai membangun tim serta mulai saling mendengarkan. Di akhir kegiatan ini mereka diminta untuk merefleksikan keadaan organisasi mereka selama ini, terutama kegiatan kegiatan dan program yang tidak berjalan dengan sempurna. Satu persatu mereka kemudian mulai bisa muncul dengan solusi solusi sederhana yang selama ini tidak mereka pikirkan.

\section{KESIMPULAN}

Diakhir kegiatan ini, ditarik kesimpulan bahwa para peserta bisa memahami kerjasama tim dan mampu untuk mengaplikasikan hal ini dalam kehidupan mereka sehingga bisa melakukan 
hal-hal yang besar yang tadinya dirasa tak mampu dilaksanakan.

\section{KEPUSTAKAAN}

Active Transformation (2007). Membangun tim yang solid. http://activetransformation.blogspot. com/2007/12/membangun-timyang-solid.html. 6 Maret 2009.

Barrick, M., and M. Mount (1991). The big five personality dimensions and job

performance: A metanalysis. Personnel Psychology 44: 1-26.

Bateman, B., C., Wilson, and D. Bingham (2002). Team effectivenessDevelopment of an audit questionnaire. The Journal of Management Development 21 (3): $215-226$.

Bryan, S., and Albrings (2006). Effective team building: Guidance for accounting educators. Journal of Accounting Education 21: 241-265.

Chang, R.Y. (1999). Membangun tim yang dinamis: Seri panduan praktis no. 8. Jakarta: Penerbit Gramedia.

Chang, R. Y. (1998). Sukses melalui kerja sama tim: Seri panduan praktis. Jakarta: Penerbit Gramedia.

Feitctner, S., and E. Davis (1992). Why some groups fail:A survey of student' experiences with learning groups. In Collaborative Learnings: A Sourcebook for Higher Education, edited by A. Goodsell, M. Maher, and V. Tinto.

Greenberg, J (1996). Managing behavior in organizations. Upper Saddle River, NJ: Prentice Hall.

Hackman, J.R (1987). The design of work teams. In Handbook of organizational Behavior, edited by J. W. Lorsch. Englewood Cliffs, NJ: Prentice Hall.

Lasahido, I. (2008). Membangun tim yang efektif.

http://www.bppk.depkeu.go.id/webp egawai/index.php?option=com_docm an\&task $=\mathrm{c}$ at view\&gid $=52 \&$ Itemid $=61 . \quad$ Diakses tanggal 27 Februari 2009.

Ray dan Bronstein (1995) Team Building ed2: Kiat membangun tim yang handal. (Alih bahasa Hananto, K.P). Jakarta: Esensi, divisi penerbit Erlangga.

Prast, D. (2008). Kualitas personal yang dibutuhkan dalam dunia kerja. http://www.dimasprast.com/2008/0 6/kualitas-personal-yang-dibutuhkan dalam.html.

Tin, Se. (2007). Membentuk soft skill mahasiswa akuntansi melalui effective team building dalam ruang kelas: sebuah aplikasi McGrath's Model. Paper dipresentasikan pada Simposium Nasional Akuntansi 10, Unhas, Makasar 
Jurnal ABDIMAS, Vol. 9, No. 1, Juni 2016 ISSN: 1979-0953 